\title{
FURTHER NOTES ON NORTH AMERICAN EPICAUTA, WITH NEW SYNONYMY (COLEOP., MELOIDAE)
}

\section{BY F. G. WERNER \\ Department of Zoology, University of Vermont}

The availability of series of several of our species of Epicauta has made possible a more thorough study of the species involved than has been possible before. Some of the more extensive necessary changes are recorded in this paper. Several of the series have been sent for determination and are acknowledged under the species. Most of the rest were collected by Dr. and Mrs. W. L. Nutting and the author during the summers of $1948^{1}$ and 1949.

\section{Epicauta emarginata Champ.}

Fipicauta emarginata Champion, 1892, Biol. Cent.-Am., Coleop. 4 (2) :426, pl. 19, fig. 24. Vaurie, 1950, American Museum Novitates No. 1477: 30.

Evicauta calcarata Werner, 1944, Psyche 50 (1943): 70;

1945, Bull. M. C. Z. 95: 477. (NEW SyNONYMY)

A long series of this species (over 150 specimens) was collected by the author 15 miles west of Lordsburg, New Mexico, Aug. 30, 1949, on flowers of a grass. Most of the specimens fit the description of calcarata. Some have broader and some have narrower tibial spurs than the holotype of that species. Two abnormally small individuals (7 nim.) have sparser pubescence and more slender legs and tibial spurs. The color of the pubescence varies from cinercous to dull yellow-cinereous, being cinereous in most.

Two paratypes of emarginata Champ., kindly loaned by Mr. J. Balfour-Browne of the British Museum, agree perfectly with some specimens in the Lordsburg series, and differ from the holotype of calcarata only in having slightly more slender posterior tibial spurs. The shape and size

This trip, for the purpose of collecting and studying Anthicidae, was mude possible by a grant-in-aid from the Society of the Sigma Xi. 
of the anterior and middle tibial spurs are precisely the same as in the type of calcarata. The two species are certainly the same.

The known range of emarginata is now from San Isidro" in Coahuila to west Texas and southeastern Arizona. I have the following additional records: TexAs: Marathon, July 9, 1938 (K. U.) ; Culbertson Co., Aug. 30, 1947, D. J. and J. N. Knull (Ohio). New Mexico: Luna Co., Oct. 1 (Ohio). Arizona: Douglas, Cochise Co., July 3, 1931, W. W. Jones (Parker); near Willcox, Cochise Co., Sept. 3, F. H. Parker, on flowers of Kallstroemia (Parker) ; Dragoon Mts., Cochise Co., Sept. 10, 1947, D. J. and J. N. Knull (Ohio and Werner).

\section{Epicauta ochrea (Lec.)}

Lytta ochrea LeConte, 1853, Proc. Acad. Nat. Sci. Phil. $6: 342$.

Epicauta ochrea, Werner, 1945, Bull. M. C. Z. $95: 495$, pl. 6, fig. 42. (See for rest of synonymy)

Epicauta moniliformis Dillon, 1950, Ent. News 61: 103. (NEW SYNONYMY)

Ochrea is probably one of the more abundant species of Epicauta in the area from west Texas to southeastern Arizona, but is nevertheless very poorly represented in collections. The reasons it is rarely collected would seem to be twofold: first, that most collectors don't know where to look for it, and second, that most collectors who do know don't care to. Specimens can be taken at the bases of leaves of yucca or bear grass (Nolina) almost any time during the summer. One encounter with the leaves of either plant is usually enough. Occasional individuals are seen in the daytime on flowers of yucca. One experience with the species on yucca flowers at night convinces me that it is primarily nocturnal, though not "attracted" to light. On July 29, 1948 we camped on the west slope of the Patagonia Mts., east of Nogales, Arizona, at $5330 \mathrm{ft}$. in the oak-juniper zone. On checking a small stand of a caulescent yucca short-

\footnotetext{
2 The only San Isidro I ean find in Coahuila in the "Atlas (ieographien de los Estados Unidos Mexicanos", Mexico, 1943, is near the Layuna dr. Viesea in the southern part of the state, on the Plateau Centrat.
} 
ly after dark, we found one plant in full bloom, with a swarm of ochrea on the blossoms, feeding on the petals and mating. We knocked down and captured several hundred specimens, losing at least twice that many in the process. They took flight readily. This night one ochrea came to our lighted sheet nearby, the only one I have ever seen at light.

The series taken at this time should provide a fair sample of the species. In it are small and large specimens, as is usual in almost any large sample of Meloidae. All mixed together, and with numerous cross-matings, are entirely ferrugineous to very dark specimens in which the elytra are ferrugineous. I have noticed this variation in color several times in the field.

Mr. Dillon has separated moniliformis on the basis of length of antennal scape, color, and width of body. Two eutopotypical specimens in the Chamberlain Collection are in the same size range as the two moniliformis types (9 and $11 \mathrm{~mm}$.). The smaller specimen, a female, is colored as in Dillon's types; the larger, a male, is uniformly ferrugineous. The lengths of the antennal scapes compare with the moniliformis description, except that in the male the scape might be just perceptibly longer.

The body form, color, and length of antennal scape can be matched in my series from the Patagonia Mts. In the same series are entirely ferrugineous specimens in coitu with dark, moniliformis-colored specimens. There seems to be a tendency for the antennal scape to be slightly shorter in the smaller specimens. In about a third of the specimens under $12 \mathrm{~mm}$. long the scape of the male antenna just reaches the hind margin of the eye; in the rest it extends beyond slightly. The measurement is a difficult one to make accurately and it often varies with the position or amount of extension of the antennae. I can see no difference in width of body in this long series or in the rest of the specimens in my collection. Apparent difference can be traced to amount of shrinkage of dried specimens, chance overlap of the elytra or amount of distension of the abdomen.

My Patagonia Mts. series shows a considerable size range, from 7 to $18 \mathrm{~mm}$., with a mean length of about $14 \mathrm{~mm}$. 
Dark specimens are more frequent among the smaller specimens but occur also among the larger.

It is my opinion that Mr. Dillon has relied too heavily on exact measurement of variable characters in distinguishing moniliformis. One of the difficulties of taxonomic work with the Meloidae is the rather large amount of variation in size and correlated variation in proportions, or in expression of secondary sexual characters.

\section{Epicauta fallax Horn}

Evpicauta fallax Horn, 1885, Trans. Am. Ent. Soc. 12: 111.

Werner, 1945, Bull. M. C. Z. 95: 450.

Kpicauta ensiformis Werner, 1944, Psyche 50(1943) : 68;

1945, op. cit.:462. (NEW SYNONYMY)

Dr. J. W. MacSwain has sent a series of fallax, from Patterson, Stanislaus Co., California, taken May 13 to June 4, 1948, by sweeping alfalfa. This series provides a much better sample of the species than was available in 1945 . On rechecking the small series from Independence, California that was used in my 1945 paper I find that all of the specimens are females. The only information I had on the male was a set of notes on the type in the Horn collection. The male differs from the female mainly in the antennae, which are long and almost ensiform. The following description of the male antennae, taken from a Patterson specimen, should be added to my earlier description. Antennae $21 / 3$ as long as an anterior tibia, reaching basal fourth of elytra. Segment I moderately slender, reaching $1 / 3$ across the eye; II small, moderately stout; III $11 / 2$ as long as I and $1 / 8$ wider at apex, slightly curved toward the posterior; IV to VII subequal in length and breadth, about $3 / 4$ as long as III; VIII to $\mathrm{X}$ equal in length, about $9 / 10$ as lono as VII, decreasing gradually in width so that $\mathrm{X}$ is about $3 / 4$ as wide as V. Proportions ${ }^{3}$ of antennal segments (to a

"These measurements are used in an effort to provide a reasonably rexact record of proportions of the individual segments. Segment 1 is given first. 'The numerators represent length, the denominators maximum width. The original measurements were made with an ocular micrometer in a stereoscopic microscope, and are accurate to ca. $\pm 0.02 \mathrm{~mm}$. For length of a segment a measurement was taken from the construction at the base, after the condyle, to the apex. The figures obtained were converted to 
total length of antenna of 1000 units): $89 / 38,43 / 33$, $124 / 47,92 / 49,94 / 54,91 / 50,91 / 49,82 / 49,89 / 48,86 / 43$, $118 / 38$. Segment $V$ is the widest and the antenna tapers gradually toward the apex, segments III to $\mathrm{X}$ being slightly flattened and obliquely truncated at the apex. The most characteristic feature is the presence of very short, appressed, dark hairs on the underside of segments III to XI. These are directed perpendicularly to the axis and point to the midline of the antenna from each side. They can be seen only with fair magnification and proper illumination. At low magnification the surface of the underside of the antenna appears glabrous and roughened; the upperside has moderately dense, suberect pubescence.

The presence of these appressed hairs on the underside of the male antenna distinguishes this species from all others in our fauna, except $E$. ensiformis. On re-checking the type specimens I feel that ensiformis is based on characters that can be extremely unsafe, the absolute length of the antennae and the width of the segments. The ratio of the lengths of antennal segments seems to provide a reasonably reliable criterion for species separation. But there is no difference in this ratio in the two. In ensiformis there seems to be mainly an exaggeration of the width and a very slight exaggeration of the length of the intermediate segments, to produce an ensiform antenna from the antenna of a normal fallax male. The types of ensiformis are like the fallax series in all other details. From experience with other species of Epicauta I am inclined to regard ensiformis as a synonym of fallax and fully expect that more extensive series will show a gradation between the two.

what they would be if the total antennal length, made up of the total of the individual lengths, were $10 \mathrm{~mm}$. and the figures represented $0.01 \mathrm{~mm}$. The total of the lengths as given is $1000 \pm 3$, the error resulting from rounding off inything under $0.01 \mathrm{~mm}$. It is hoped that this system of recording measurements will prove superior to a segment-by-segment comparison. where errors accumulate as one progresses. It is also hoped that the antennae of different species will be more easily compared, since all would be converted to a standard $10 \mathrm{~mm}$. length. The figures must not be taken as entirely diagnostic, however. They are to be considered as representing the antennas of a single "typleal" sperimen. 
Epicauta diversipubescens Mayd.

Epicauta diversipubescens Maydell, 1934, Trans. Am. Ent. Soc. 60: 333. Werner, 1945, Bull. M. C. Z. 95: 487.

Mr. H. B. Leech of the California Academy of Sciences has pointed out to me that the Leng Collection of Meloidae contains three specimens bearing the locality labels of Maydell's first three specimens and that each bears a red “TYPE" label, probably put on by Maydell. I find from my notes that the specimen in the U.S. N. M. which I had thought to be the holotype in 1945 was without locality label. This evidence supports Mr. Leech's contention that I saw one of the paratypes and that the holotype is now in the California Academy. This specimen seems to be a male, from Mr. Leech's description, and is further distinguished by the lack of all but the two basal segments of the left antenna and in having a hole eaten out of one side of the abdomen.

\section{Epicauta jimenezi Dugès}

Epicauta jimenezi Dugès, 1889, Anales del Museo Michoacano 2: 73. Champion, 1892, Biol. Cent.-Am., Coleop. 4 (2) : 417. Vaurie, 1950, American Museum Novitates No. $1477: 23$.

Epicauta nigropilosa Maydell, 1934, Trans. Am. Ent. Soc. $60: 332$. (NEW SYNONYMY)

Maydell seems to have been misled by Dugès' description of this insect, which was black, with the "Elitros grandes, de forma normal, granulosos y pubescentes, ferruginosooscuro con bonitos reflejos color de purpura." A specimen in the Instituto de Biologia, Mexico, D. F., is labeled jimen$e z i$ E. Dugès and bears a pin label "Guadalajara". This is almost certainly one of Dugès' type specimens. Maydell's type specimen, one of a series well distributed in collections, is certainly a specimen of jimenezi, one of the most distinct of the genus in Mexico. The "purple" reflections on the elytra are equally well seen in the jimenezi type or in nigropilosa eutopotypes, the color being produced by sparse black pubescence over rufo-testaceous background, much as the rufous pubescence over a black background produces the "purple" of purpurea. 
The species is discussed here because certain specimens from southern Arizona appear to be assignable to it. These specimens from Arizona do not agree completely with a series from Guadalajara, differing mainly in the color of the elytra. The species is redescribed on the basis of a male specimen from Guadalajara; following the redescription a comparison is made with the Arizona specimens.

Black, the elytra rufo-testaceous, but with short black pubescence that darkens the color. Length $22 \mathrm{~mm}$.; width across base of elytra $6.5 \mathrm{~mm}$. Head subquadrate, as broad as long to apex of clypeus; surface densely punctured except along a narrow midline, opaque because of deep microreticulation. Antennal calluses not evident, being marked only by the slightly sparser, irregular punctures. Pubescence moderately dense but short, black, decumbent except along the lateral margins, where it is erect and longer. Eyes nooderately narrow, 0.45 as broad as long, not very prominent. Antennae slender, 2.7 as long as an anterior tibia, 12 mn. long. Segment I moderately slender, reaching $2 / 3$ across the eye, almost parallel-sided; II short; III and following slender, slightly flattened, all but XI slightly wider at apex than at base. Proportions of segments (to total length of 1000 units): 108/42, 51/29, 128/33, 101/37, $93 / 37,93 / 35,93 / 33,88 / 33,79 / 30,75 / 29,93 / 27$. Maxillary palpi of male slightly enlarged and flattened, glabrous beneath; labial palpi just perceptibly enlarged, also glabrous beneath.

Pronotum subquadrate, just perceptibly broader than long. Surface densely punctured, with microreticulation as on head, and with short, subdecumbent to erect pubescence. Median impressed line distinct on middle of disc; median ar'ea depressed toward base. Scutellum black. Elytra rufotestaceous, more shallowly and sparsely punctured than the pronotum but equally opaque. Pubescence black, short, decumbent, moderately sparse but giving a darker tinge to the color of the elytra. Anterior tibial spurs slender, straight in both sexes. Male anterior tarsi with a dense flat pad, broadened particularly on the first segment, decreasing gradually in width to segment 4 . The pad of segment 1 of the male is 1.9 as long as in a female of comparable size, and 1.7 as wide. In the female the pad is not as dense 
or as flat as in the male and is of almost uniform width on segments 1 to 4 . Posterior tibial spurs slender, sticklike, the outer shorter. Underside entirely black.

The three Arizona specimens before me are 18, 20 and $21 \mathrm{~mm}$. long and are of the same proportions as the Guadalajara specimens. They differ only in having the elytra dark chocolate brown, made to appear almost black by the black pubescence. Three specimens from Champion's series are also available, through the courtesy of Mr. J. BalfourBrowne of the British Museum. Two are from Canelas and one from Ventanas, in Durango. These, and one specimen collected by myself in Tepic, Nayarit, have the elytral color intermediate between the Guadalajara and the Arizona specimens. For this reason I believe it would be preferable to postulate a North-South cline in elytral color, rather than subspecific relationship.

The species in our fauna that Arizona jimenezi specimens mont closely resemble is corvina (Lec.). They differ in being opaque rather than slightly shiny and in having the elytra a bit narrower. The greater opacity is caused by the denser punctures and particularly by the deeper microreticulation. The middle and hind tibiae of jimenezi males are almost straight, as in the female, while in corvina males they are slightly flattened, broader and more bowed than in the female. The anterior tarsal pads of the male of corvina are denser, broader and flatter than in the female but the pad on segment 1 is shorter than in the male of jimenezi, being only about 1.5 as long as in the female of its own species. The two species are otherwise so similar that they must be very closely related. Arizona specimens will key to corvina in my 1945 key but can be distinguished by the characters given above.

Type locality: Guadalajara, Jalisco, Mexico. (of nigropilosa Mayd.: same locality, Aug. 17, 1903, McClendon). Additional records: Mexico: 1, Tepic, Nayarit, July 22, 1952, F. W. \& F. G. Werner, on flowers of a Composite (FW) ; Ventanas, Durango, Forrer; and Canelas, Durrango, Becker (BMNH). ARIzoNA: 1 male, Patagonia, July 4, 1929, F. W. Nunenmacher Coll. (CNHM) ; 1 female, W. slope of Patagonia Mts. on Lochiel Road, St. Cruz Co., 5330 ft. in oak-juniper zone, July 28, 1948, W. 
L. Nutting \& F. G. Werner (FW) ; 1 female, Tumacacori Mts., July 22, 1940, D. J. \& J. N. Knull (Parker).

\section{Epicauta languida (Horn)}

Macrobasis languida Horn, 1895, Proc. Calif. Acad. Sci. (2) $5: 252$.

Expicauta languida, Werner, 1945, Bull. M. C. Z. 95 : 424, 501.

The California Academy of Sciences has a small series of this species, as well as the holotype. Below is a short redescription, based on notes taken on the holotype (No. $154)$, seen in 1946, and checked at that time with the more recent specimens. The species should be left in my group $A$, in which the male does not have a row of stout apical teeth on the metatibia, and should be placed near excors and tenuilineata.

Color luteous, with the antennae brown. Pubescence tannish cinereous, depressed. Elytra with humeral and scutellar dark markings. Head narrowly ovate, the surface densely punctured, with the intervals punctulate. Median impressed line fine, distinct down to the level of the hind miargin of the eyes. Antennal calluses denuded, smooth, of moderate size and only slightly raised. Eyes transverse, moderately narrow, emarginate. Male antennae $31 / 2$ as long as an anterior tibia. Segment I flat, straight, reaching almost to occiput; II almost as long as I, flattened, slightly curved; III short, $1 / 3$ as long as II, $2 / 3$ as long as IV; IV the largest of the succeeding segments, rest just slightly shorter, slender, slightly flattened. Female antennae with segment I reaching hind margin of the eye; II almost as long as I; III approximately $1 / 2$ as long as II; IV and folIr) wing equal, almost as long as II. Pronotum campanuliform, 1/4 longer than broad; median impressed line distinct from $1 / 4$ from base to $1 / 3$ from apex; a prominent impression at middle of base. Anterior tibiae of male with two spurs, the inner slightly the shorter; male anterior tarsi not modified. Posterior tibial spurs spiniform, only very slightly broadened. Underside not marked. Legs marked as in polingi Werner.

Distribution: BAJA CALIFORNIA: Beside the holotype from $S$ s.n José del Cabo there are specimens in the California 
Academy of Sciences collected by Michelbacher and Ross, from 10 mi. N.W. of LaPaz, Oct. 6, 1941; Arroyo Seco, Oct. 6; San Venancio, Oct. 8; and Agua Caliente, Cape Region, Oct. 18. It is thus far known only from the southern part of the peninsula.

New England Records of Ululodes Currie (NeuropTERA: AsCALAPHIDAE). - There are few records of the two indigenous species of Ululodes from the northeastern corner of the United States. The genus is not mentioned in Procter's Biological Survey of the Mount Desert Region [Maine], Part VII, 1946, nor is it recorded by Johnson in his Insects of Nantucket, 1930, or by Britton in the checkList of the Insects of Connecticut, 1920 and 1938. There is only one citation in Leonard's List of the Insects of New York, 1926; and this is of U. quadripunctata from Staten Island, in the extreme southeast. Records of both species are more plentiful in Smith's Insects of New Jersey, 1910, and Brimley's Insects of North Carolina, 1938; the former work citing two localities for $U$. hyalina and five for $U$. quadripunctata, and the latter, four and two localities for these species, respectively.

Inasmuch as they represent extensions of the known ranges of both species, the following records from the author's collections are presented herewith, even though lacking such desirable data as precise locality and year of collection: Ululodes hyalina Latr., Marthas Vineyard, Massachusetts, 19 July, 1 specimen at light. Ululodes quadripunctata Burm., Marthas Vineyard, Mass., 2 August, 1 specimen at light; New London, Connecticut, July-August, 1948, 1 specimen. In all cases, poor condition precludes determination of sex of these specimens. The author will gratefully receive any records or specimens of Ululodes from the northeastern United States. - George H. Beatty, III, Plumsteadville, Pennsylvania. 

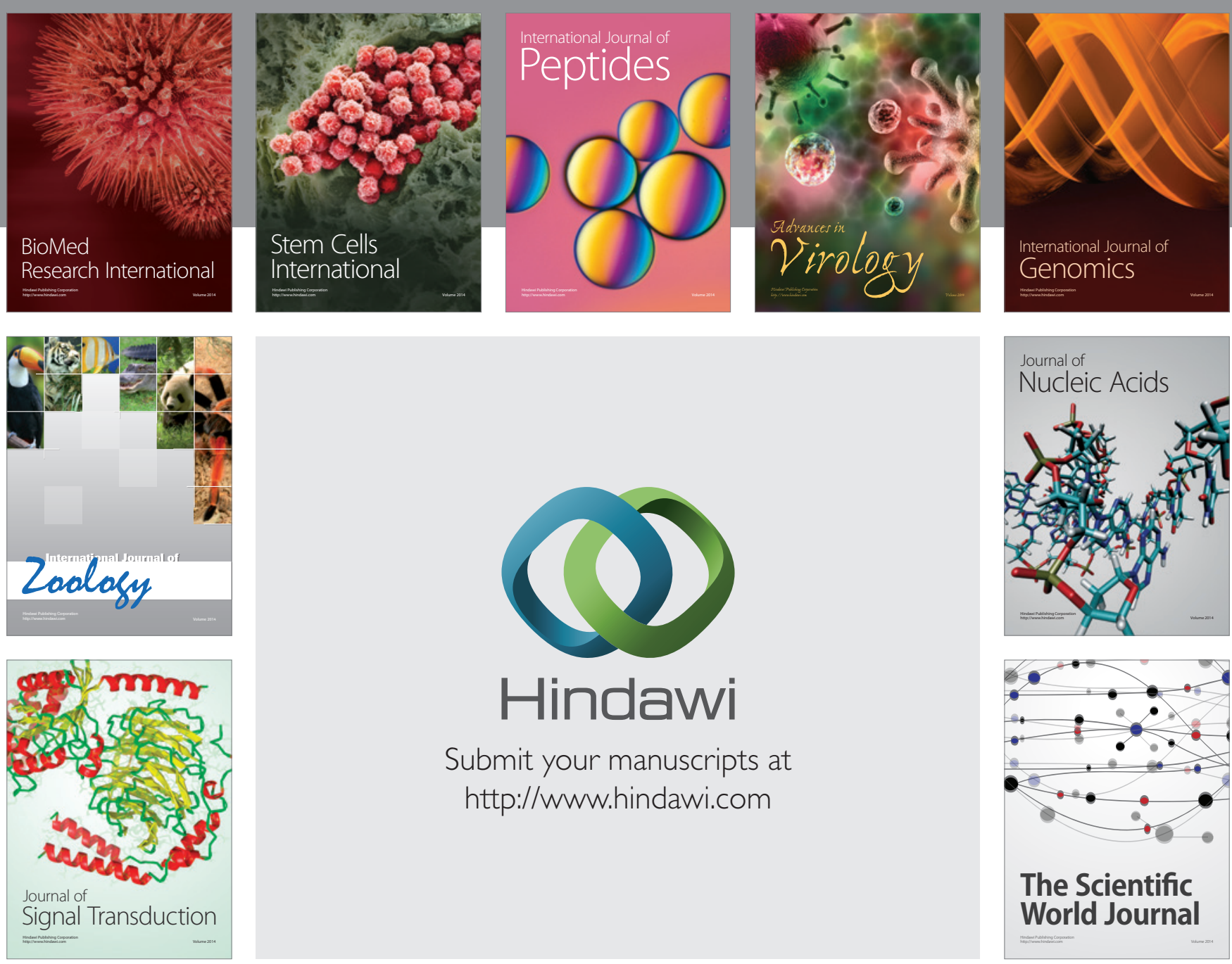

Submit your manuscripts at

http://www.hindawi.com
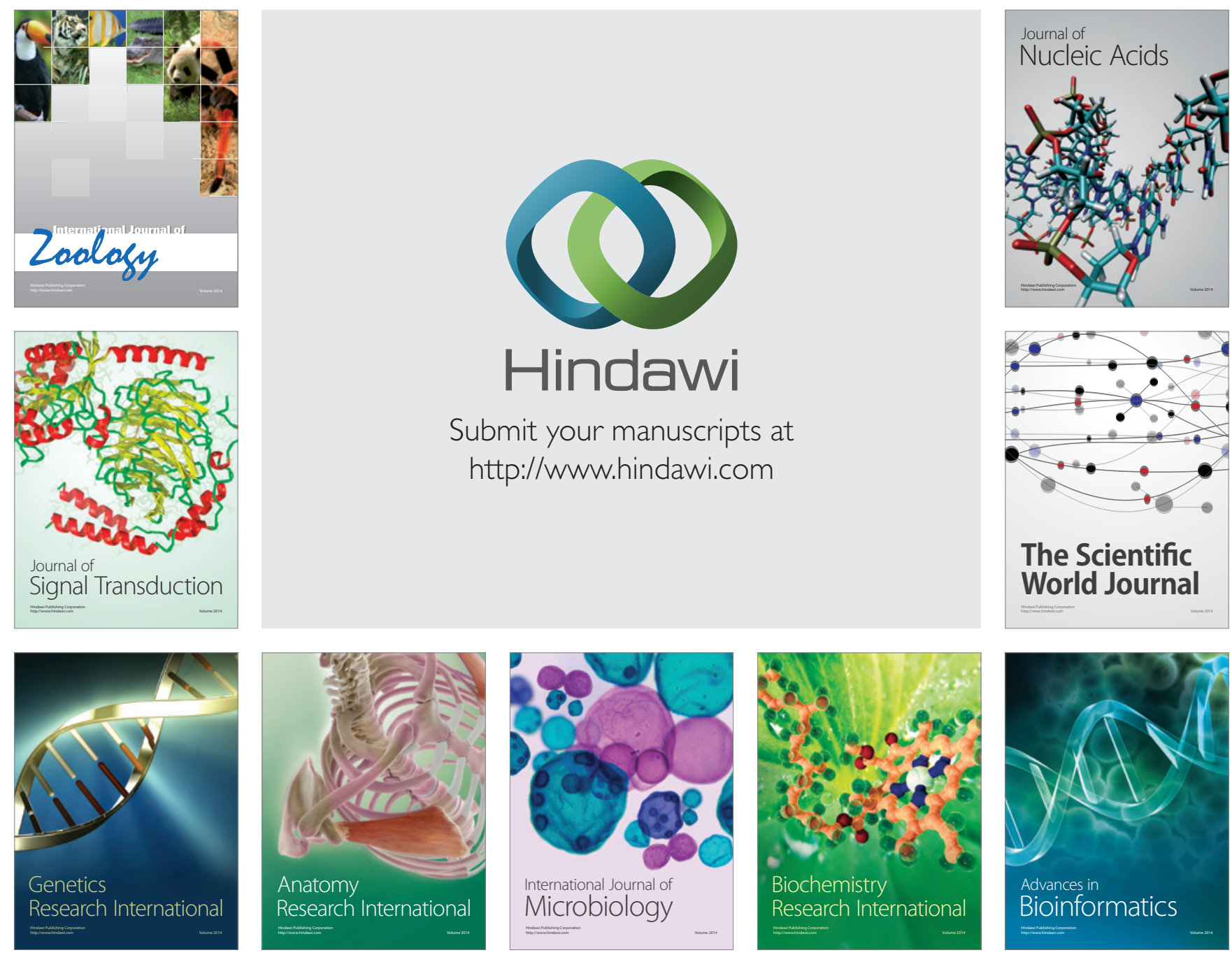

The Scientific World Journal
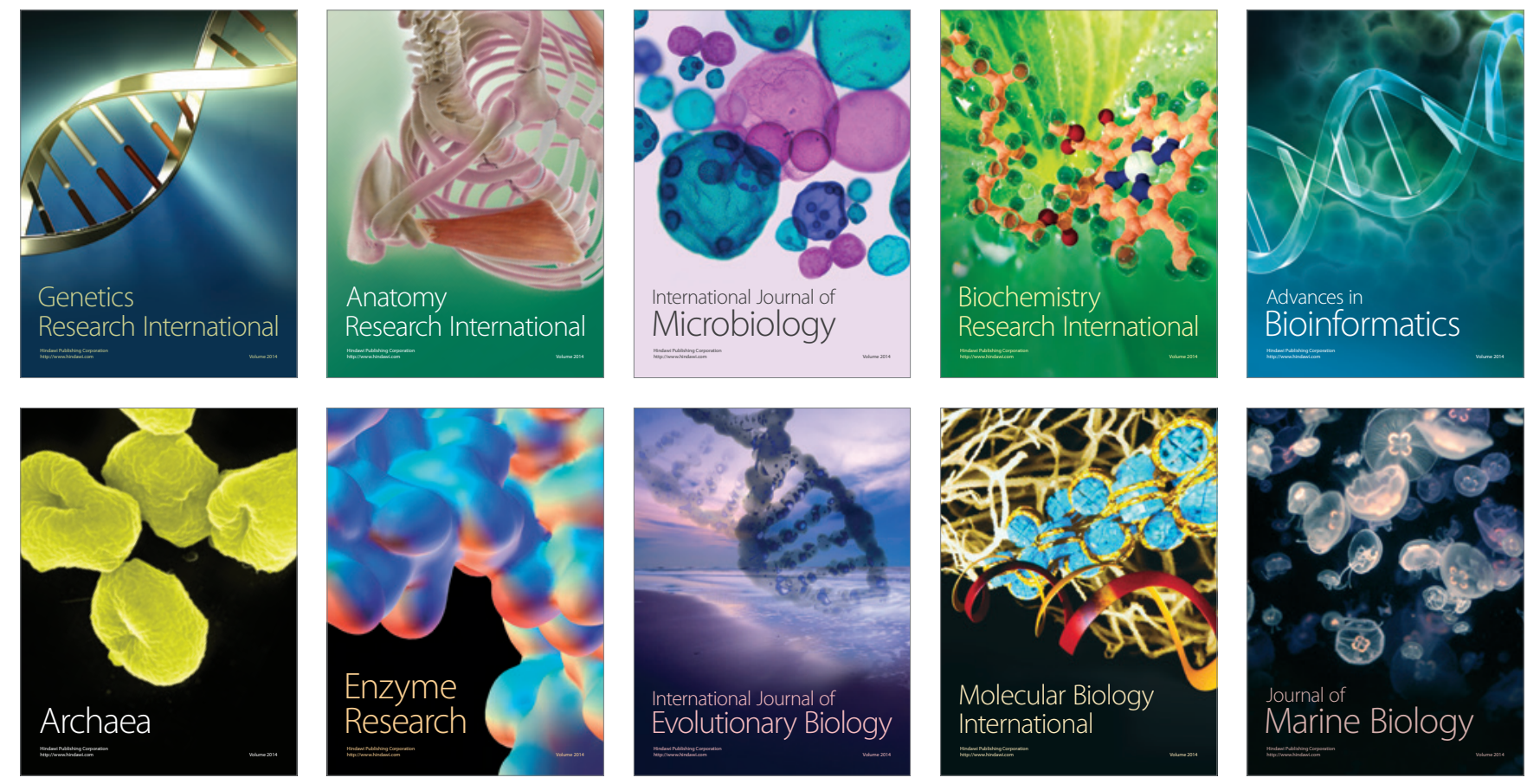